
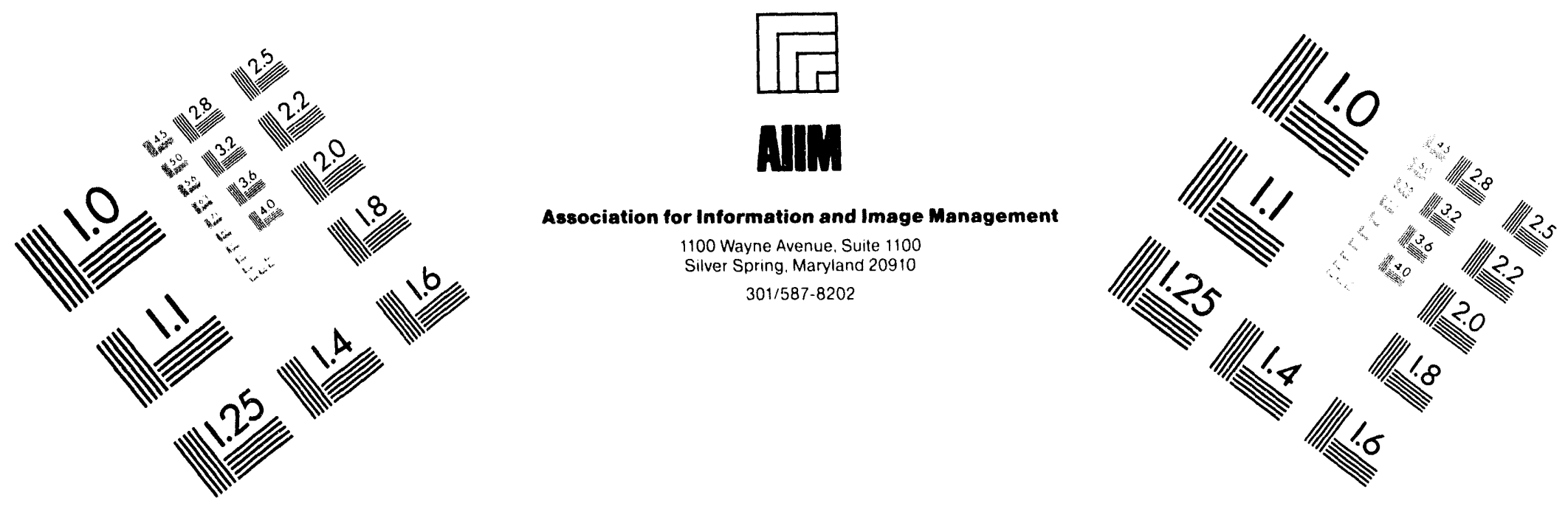

\title{
Centimeter
}

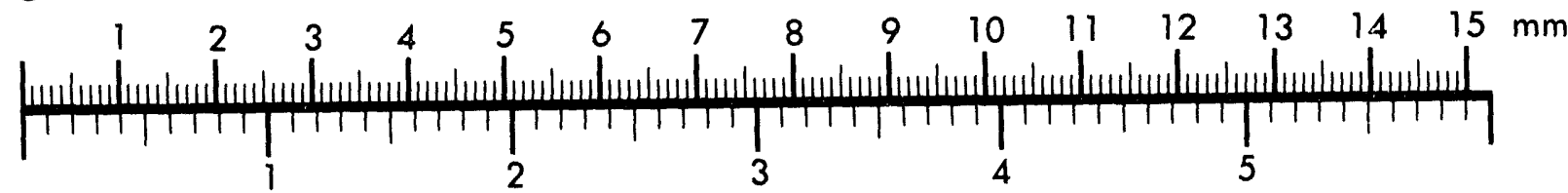
Inches
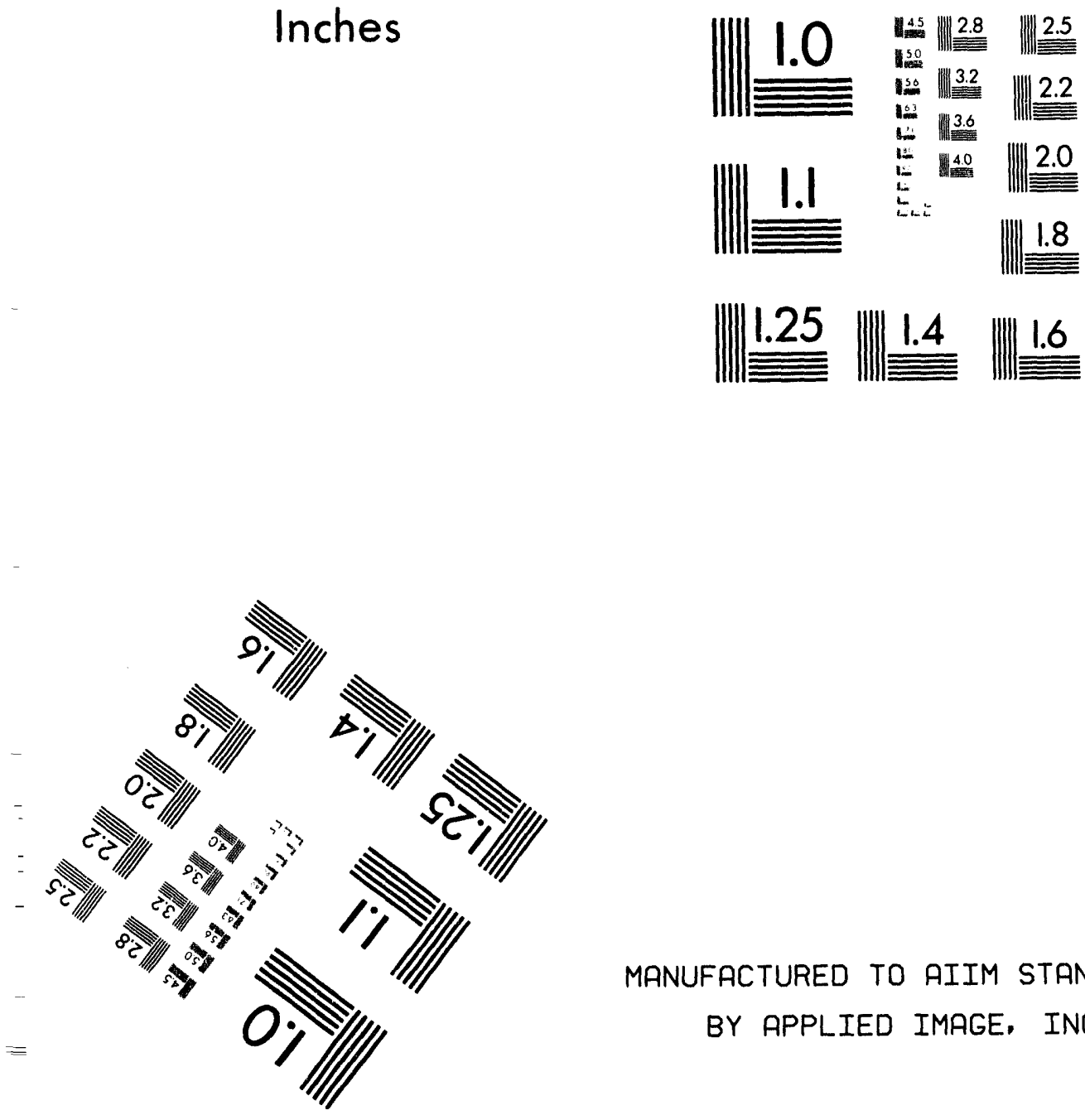

MANUFACTURED TO AIIM STANDARDS

BY APPLIED IMAGE, INC.

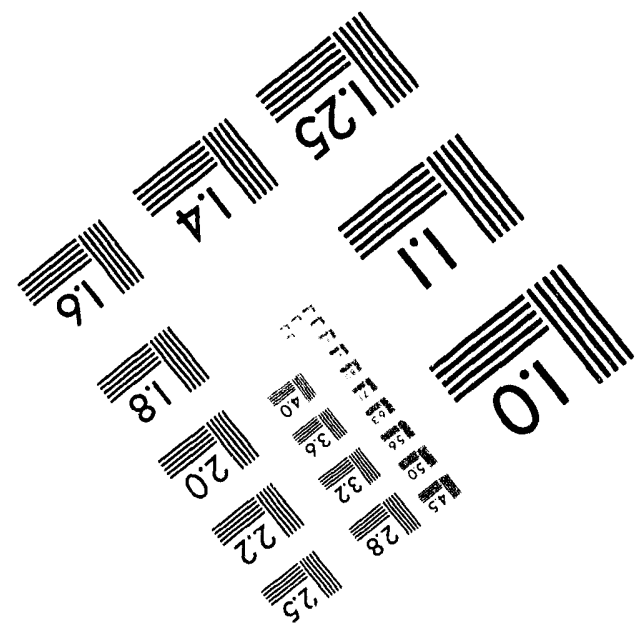



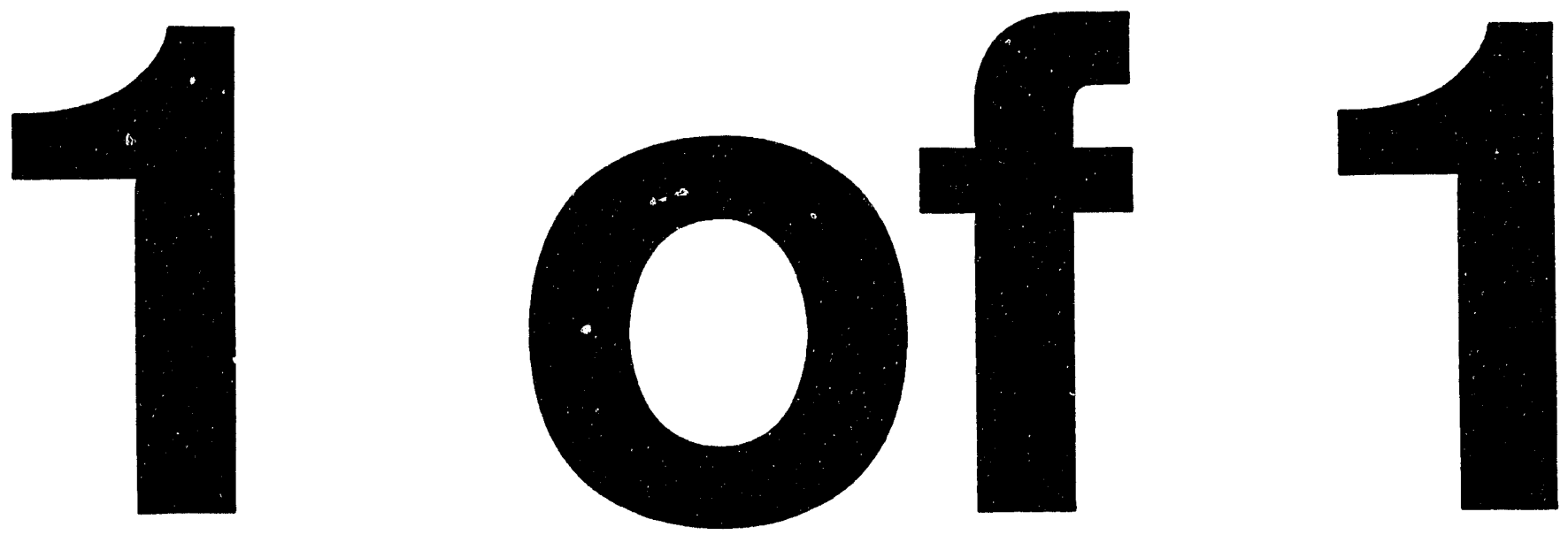


$$
\text { Conf } 940248-2
$$

\section{Testing of a Peroxidation Systems, Inc. perox-pure SSB-30}

K. M. Hodgson
T. R. Lunsford

Date Published

February 1994

To Be Presented at

Chemical Oxidation: Technology

for the Nineties Symposium

Nashville, Tennesee

February 16-18, 1994

Prepared for the U.S. Department of Energy Office of Environmental Restoration and

Waste Management

\section{$\begin{array}{ll}\text { (2.) Westinghouse } & \text { P.O. Box } 1970 \\ \text { Hanford Company } & \text { Richland, Washington } 99352\end{array}$}

Hanford Operations and Engineering Contractor for the

U.S. Department of Energy under Contract DE-AC06-87RL10930

Copyright License By acceptance of this article. the publisher and/or tecipient acknowledges the US Government s right to retain a nonexclusive, royalty-tres license in and to any copyright covering this paper.

Approved for Public Release

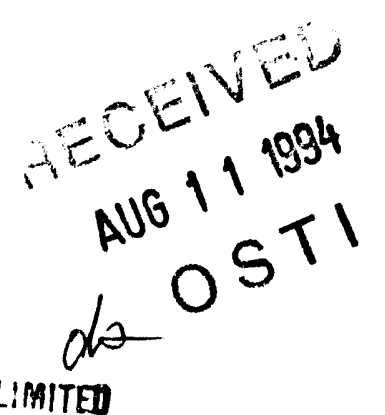




\section{LEGAL DISCLAIMER}

This report was prepared as an account of work sponsored by an agency of the United States Government. Neither the United States Government nor any agency thereol. nor any of their employees, nor any of their contractors, subcontractors or their employees. makes any warranty, express or implied. or assumes any legal liability or responsibility for the accuracy, completeness, or any third party's use or the results of such use of any information, apparatus, product, or process disclosed, or represents that its use would not intringe privately owned rights. Reierence herein to any specific commercial product, process. or service by trade name. trademark, manulacturer, or otherwise, does not necessarily constitute or imply its endorsement. recommendation, or favoring by the United States Government or any agency thereot or its contractors or subcontractors. The views and opinions of authors expressed herein do not necessarily state or reflect those of the United States Government or any ayency thereot.

This report has been reproduced from the best available copy.

Printed in the United States of America

DISCLM-2.CHP $(1.91)$ 


\begin{abstract}
A facility is being designed and built at the U.S. Department of Energy (DOE) Hanford Site to treat water containing a variety of organic and inorganic compounds. An ultraviolet light/hydrogen peroxide system, manufactured by Peroxidation Systems, Inc. (PSI), has been chosen to destroy the organic compounds in the feed stream. The PSI perox-pure $^{\mathrm{TM} *}$ model SSB-30 has been tested by tile Westinghouse Hanford Company (WHC) to provide data for permit documentation and to determine appropriate operating conditions. The destruction of the organic compounds was demonstrated with several feed compositions at different ultraviolet light exposures and hydrogen peroxide concentrations.
\end{abstract}

\title{
INTRODUCTION
}

In the past, the chemical processing facilities at the Hanford Site allowed large quantities of water with low levels of radionuclides to be discharged to shallow, sandy sediments below the ground surface. Favorable adsorption and filtration characteristics meant that most of the radionuclides were retained in a sediment column above the water table. Subsequently, the DOE implemented a policy requiring waste water treatment and minimization of radioactive and hazardous waste discharge. As a result, several projects have been initiated to treat major waste water streams and to remove radioactive and hazardous components from them.

One of the projects, the 200 Area Effluent Treatment Facility (ETF), will provide the facilities to treat and dispose of the 242-A Evaporator process condensate. Originally, ETF was designed to treat 242-A Evapo .tor process condensate and the process distillate discharge and the ammonia scrubber distillate of the Plutonium Uranium Extraction Plant (PUREX). Because the PUREX Plant was shut down by the DOE in January 1993, it

\footnotetext{
* perox-pure $^{\mathrm{TM}}$ is a registered trademark of Peroxidation Systems, Inc.
}

Authors are K. M. Hodgson and T. R. Lunsford, Westinghouse Hanford Company, P.O. Box 1970, Richland, Washington, 99352. 
is unlikely that the PUREX process distillate discharge and the ammonia scrubber distillate will be generated again. Therefore it is necessary only to address the treatment of 242-A Evaporator process condensate.

The process condensate is formed by the evaporation process which occurs when the 242-A Evaporator concentrates low-level waste stored in underground double-shell tanks. The double-shell tank waste and the process condensate are considered dangerous under the Washington Administrative Code (WAC) Chapter 173-303 [1] and the U.S. Environmental Protection Agency (EPA) regulations [40 Code of Federal Regulations 261] [2] because of the presence of the following:

- Halogenated spent solvents (F001 and F002) and nonhalogenated spent solvents (F003 and F005)

- $\quad$ Toxicity (WT02 per WAC 173-303)

- Radionuclides such as tritium, strontium-90, ruthenium-106, and cesium-137

- Inorganic compounds such as ammonia, potassium, silica, carbonate, chloride, and nitrate

- Organic compounds such as butyl alcohol, aceione, tetradecane, tridecane, and tributyl phosphate

The treatment system is illustrated in Figure 1. Treatment consists of the following steps:

1. Removal of suspended solids by filtration, and removal of organic compounds by the PSI ultraviolet light mediated oxidation process. The process utilizes hydrogen peroxide as an oxidant to promote the destruction of organic impurities.

2. Conversion of dissolved ammonia to ammonium sulfate by adding sulfuric acid to achieve a pH of 4 to 6 .

3. Removal of most of the dissolved solids using a reverse osmosis unit. The retentate (concentrated stream) from this unit will be concentrated to the lowest possible volume.

4. Using an ion exchange/adsorption system for dissolved solids polishing. This will assure that the goals for removing radionuclides and dissolved solids will be met.

5. Adjusting the $\mathrm{pH}$ in-line from 6.5 to 8.5 .

After being treated in the ETF, the effluent will be sent to holding tanks for sampling and analytical verification. If the effluent meets permit conditions, then it will be discharged to a State Approved Land Disposal Site. 


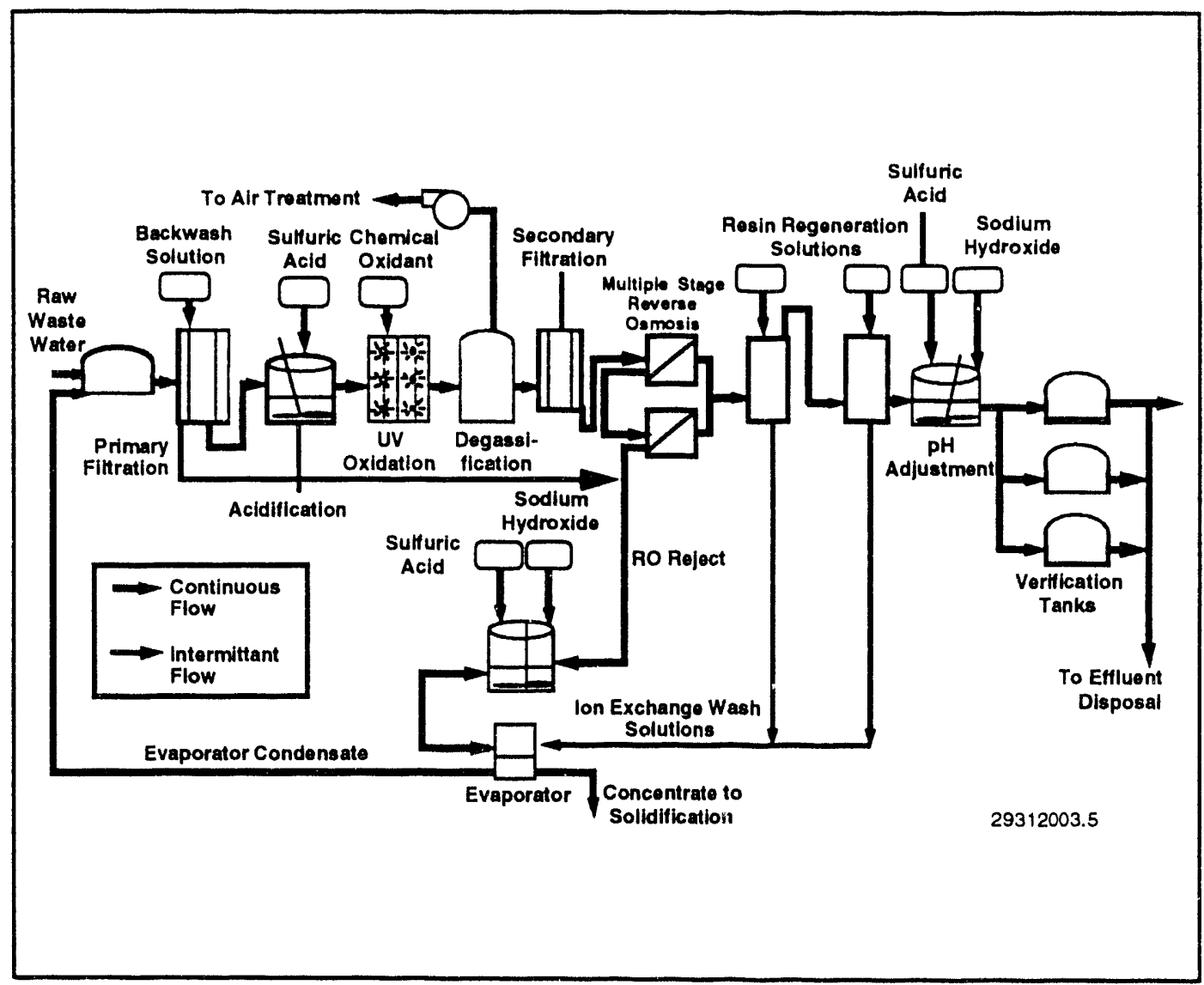

Figure 1. Treatment Flow Diagram for the 200 Area Effluent Treatment Plant.

Surrogate wastes were selected for testing because the 242-A Evaporator is shut down, and no waste water is available for pilot testing. Even when the evaporator restarts, the initial condensate produced will be too dilute to make it suitable for pilot testing.

Surrogate test solutions (STSs) were developed to contain carefully selected chemicals representing the types of constituents that will be of concern in the anticipated waste stream to be treated at the ETF. The solutions also contain various other organic and inorganic chemical groups expected to be found on the Hanford Site.

\section{OBJECTIVE}

The objective of testing was to demonstrate the concentration ranges of organic compounds that can be successfully treated by the ultraviolet light/hydrogen peroxide process in the ETF. The testing formed the basis of a petition to the EPA to delist the ETF effiuent. 


\section{SCOPE}

Testing included determining the destruction and removal efficiencies of the ultraviolet light/hydrogen peroxide, reverse osmosis, and ion exchange portions of the process. Only the results of the ultraviolet light portion of the testing are discussed. Testing was not intended to simulate a continuous ETF treatment train. Tests were performed in a semicontinuous mode where the surrogate test solution was sequentially processed through each step.

\section{SURROGATE TEST SOLUTIONS}

Surrogate Test Solutions composed of constituents characterizing the 242-A Evaporator process condensate were used for testing. Additional constituents were also included to expand the types of constituents that might be treated by the ETF. The STS constituents were selocted from the 242-A Evaporator process condensate characterization data, the Hanford Site chemical inventory, and additional organic compounds representing various chemicals of regulatory concern. For a detailed explanation of STS development, see C-018H Surrogate Test Solution [3].

The STSs were tailored specifically to evaluate the ultraviolet oxidation rate of organic compounds, and the removal efficiency of inorganic compounds using reverse osmosis and ion exchange. Four solutions were developed and tested. For additional information, see the Envelope Test Plan [4] which is summarized as follows:

STS-1: STS-1 is considered "worst-case" waste. It consists of high concentrations of inorganic and organic constituents found in the 242-A Evaporator PC and identified in the Hanford chemical inventory [5].

STS-2: STS-2 is composed of typical concentrations of organic constituents found in the 242-A Evaporator process condensate and has high inorganic constituent concentrations. It also includes constituents identified in the Hanford Site chemical inventory [5]. This STS formulation was used primarily to evaluate the high inorganic concentration effect on the ultraviolet light mediated oxidation system.

STS-3: STS-3 is considered a more "typical case" waste. It consists of inorganic and organic constituents found in the 242-A Evaporator process condensate and identified in the Hanford Site chemical inventory [5].

STS-4: STS-4 is composed of high concentrations of inorganic constituents found in the 242-A Evaporator process condensate and identified in the Hanford Site chemical inventory [5] as well as organic constituents representing various chemical groups of regulatory concern. This STS formulation was used primarily to evaluate the high inorganic concentration effect on the organic oxidation of constituents of regulatory concern. 
Each STS was prepared in a concentrated form and diluted to the correct volume before each test. Specific volatilization prevention techniques were implemented to minimize loss of organic compounds during STS preparation. The solutions were sampled immediately before the initiation of each test. The STS preparation is discussed in the following section.

\section{SURROGATE TEST SOLUTION PREPARATION}

Target constituent concentrations for each STS were reported in the C-018H Surrogate Test Solution document [3]. Hanford's Standards Laboratory in the 222-S Laboratory Complex prepared the concentrates for each solution based on the target constituent concentrations [3]. The prepared compositions of the STSs are given in Tables I and II. Each STS was prepared from concentrates of the inorganic, volatile organic, and semivolatile organic constituents and was then diluted to the full 200 gallon test volume.

Before beginning each test, the STS concentrate was fully diluted to 200 gallons. Exactly 195 gallons of deionized water was used as a diluent for the tests. The water was weighed in 55-gallon polyethylene containers on a calibrated scale. The mass was converted to volume using the density of water at the bulk temperature of the water. The water, except for approximately 5-gallons retained for rinsing purposes, was pumped into the ultraviolet light mediated oxidation feed/recycle tank.

\section{TESTING}

Tests were ordered as follows: STS-3, STS-1, STS-2, and STS-4. The STS-3 was chosen as the starting point because organic and inorganic concentrations are representative of the actual feed to the ETF. The STS-1 test, which followed, represented the most challenging feed with high concentrations of both organic and inorganic constituents. The STS- 2 test had low organic and high inorganic concentrations. The STS-4 test was last because of its unique combination of organic compounds.

\section{TEST CONDITIONS}

The conditions of the ultraviolet light mediated oxidation testing are summarized in Table III. The oxidation time and hydrogen peroxide concentrations selected were based on the organic and inorganic compositions of the STSs. Oxidation time and hydrogen peroxide concentration were adjusted to compensate for variations in the feed composition and to demonstrate the flexibility and capability of the ultraviolet light mediated oxidation process to treat feed streams with varying organic and inorganic 
TABLE I. PREPARED COMPOSITIONS OF THE SURROGATE TEST SOLUTIONS (ORGANIC).

\begin{tabular}{|c|c|c|c|c|}
\hline Analyte & $\begin{array}{c}\text { STS-1 } \\
\text { Prepared } \\
\text { Concentration } \\
\text { (ppb) }\end{array}$ & $\begin{array}{c}\text { STS-2 } \\
\text { Prepared } \\
\text { Concentration } \\
\text { (ppb) }\end{array}$ & $\begin{array}{c}\text { STS-3 } \\
\text { Prepared } \\
\text { Concentration } \\
(\mathrm{ppb})\end{array}$ & $\begin{array}{c}\text { STS-4 } \\
\text { Prepared } \\
\text { Concentratio } \\
\mathrm{n} \\
\text { (ppb) }\end{array}$ \\
\hline Acetone & 24,983 & 2,498 & 2,498 & \\
\hline Acetonitrile & & & & 2,498 \\
\hline Acrolein & & & & 2,497 \\
\hline Aniline & & & & 4,994 \\
\hline Benzene & 2,495 & 250 & 249 & \\
\hline Bis (2-chloroethyl) ether & & & & 2,491 \\
\hline Bis (2-ethylhexyl) phthalate & & & & 100 \\
\hline n-Butanol & 100,353 & 9,990 & 10,035 & 14,092 \\
\hline Carbon Tetrachloride & 2,498 & 251 & 251 & \\
\hline Chloroform & 2,504 & 250 & 250 & \\
\hline 1,4-dichlorobenzene & & & & 4,994 \\
\hline gamma-BHC & & & & 1,998 \\
\hline Hexachloroethane & & & & 2,498 \\
\hline Methyl ethyl ketone & 4,997 & 500 & 494 & \\
\hline Methyl isobutyl ketone & 4,996 & 500 & 496 & \\
\hline Naphthalene & 2,498 & 250 & 250 & \\
\hline Nitrobenzene & & & & 4,991 \\
\hline N-nitroso-di-n-propylamine & & & & 2,497 \\
\hline Pentachlorophenol & & & & 2,497 \\
\hline Phenol & 2,496 & 250 & 250 & \\
\hline Pyridine & 2,499 & 251 & 252 & \\
\hline Toluene & 2,498 & 249 & 251 & \\
\hline Tributyl phosphate & 14,985 & 9,989 & 10,007 & 7,056 \\
\hline 1,1,1-Trichloroethane & 2,507 & 251 & 249 & \\
\hline Tridecane & 999 & 999 & 989 & 999 \\
\hline
\end{tabular}


TABLE II. PREPARED COMPOSITIONS OF THE SURROGATE TEST SOLUTIONS (INORGANIC).

\begin{tabular}{|l|c|c|c|c|}
\hline Analyte & $\begin{array}{c}\text { STS-1 } \\
\text { Prepared } \\
\text { Concentration } \\
(\mathrm{ppb})\end{array}$ & $\begin{array}{c}\text { STS-2 } \\
\text { Prepared } \\
\text { Concentration } \\
(\mathrm{ppb})\end{array}$ & $\begin{array}{c}\text { STS-3 } \\
\text { Prepared } \\
\text { Concentration } \\
(\mathrm{ppb})\end{array}$ & $\begin{array}{c}\text { STS-4 } \\
\text { Prepared } \\
\text { Concentration } \\
(\mathrm{ppb})\end{array}$ \\
\hline Aluminum & 5,020 & 4,995 & 1,249 & 4,955 \\
\hline Ammonium & $2,509,075$ & $2,497,490$ & 49,968 & $2,497,464$ \\
\hline Arsenic & 2,510 & 2,497 & 407 & 2,497 \\
\hline Barium & 201 & 200 & 100 & 200 \\
\hline Beryllium & 100 & 100 & 75 & 100 \\
\hline Cadmium & 1,004 & 999 & 500 & 999 \\
\hline Cesium & 502 & 500 & 100 & 499 \\
\hline Chromium & 2,510 & 2,497 & 499 & 2,498 \\
\hline Copper & 1,004 & 999 & 489 & 999 \\
\hline Iron & 502 & 499 & 250 & 499 \\
\hline Lead & 100 & 100 & 50 & 100 \\
\hline Mercury & 100 & 100 & 50 & 100 \\
\hline Nickel & 1,004 & 999 & 499 & 999 \\
\hline Ruthenium & 764 & 761 & 152 & 761 \\
\hline Selenium & 1,005 & 985 & 858 & 1,000 \\
\hline Silicon & 4,415 & 4,392 & 2,196 & 4,391 \\
\hline Silver & 201 & 200 & 100 & 200 \\
\hline Sodium & 44,314 & 44,086 & 12,230 & 44,091 \\
\hline Strontium & 502 & 499 & 100 & 499 \\
\hline Vanadium & 502 & 499 & 100 & 499 \\
\hline Zinc & 1,004 & 999 & 499 & 999 \\
\hline Carbonate & 10,046 & 10,006 & 2,498 & 9,990 \\
\hline Chloride & 1,760 & 1,752 & 635 & 1,752 \\
\hline Cyanide & 2,008 & 1,999 & 499 & 1,998 \\
\hline Fluoride & 25,099 & 24,975 & 4,995 & 24,975 \\
\hline Nitrate & $1,058,532$ & $1,057,874$ & 61,364 & $1,057,814$ \\
\hline Sulfate & $6,282,532$ & $6,250,222$ & 101,080 & $6,250,221$ \\
\hline
\end{tabular}


TABLE III. ULTRAVIOLET LIGHT MEDIATED OXIDATION TESTING PARAMETERS AND SAMPLE TIMES.

\begin{tabular}{|l|l|l|l|l|}
\hline \multicolumn{1}{|c|}{ Parameter } & \multicolumn{1}{|c|}{ STS-1 } & \multicolumn{1}{c|}{ STS-2 } & \multicolumn{1}{c|}{ STS-3 } & \multicolumn{1}{c|}{ STS-4 } \\
\hline $\begin{array}{l}\text { Initial hydrogen } \\
\text { peroxide concentration } \\
\text { (mg/L) }\end{array}$ & 500 & 250 & 250 & 500 \\
\hline $\begin{array}{l}\text { Hydrogen peroxide } \\
\text { concentration (mg/L) } \\
\text { after } 1 / 3 \text { of oxidation } \\
\text { time }\end{array}$ & $\begin{array}{l}50 \text { after } \\
204 \text { minutes }\end{array}$ & $\begin{array}{l}50 \text { after } \\
111 \text { minutes }\end{array}$ & $\begin{array}{l}50 \text { after } \\
44 \text { minutes }\end{array}$ & $\begin{array}{l}200 \text { after } \\
22 \text { minutes }\end{array}$ \\
\hline Oxidation time & 46 & 25 & 10 & 5 \\
\hline $\begin{array}{l}\text { Test duration } \\
\text { (minutes) }\end{array}$ & 613 & 333 & 133 & 67 \\
\hline $\begin{array}{l}\text { Protocol } \\
\text { characterization } \\
\text { sampling times }\end{array}$ & $\begin{array}{l}\text { Every 10 } \\
\text { minutes of } \\
\text { oxidation } \\
\text { time }\end{array}$ & $\begin{array}{l}\text { Every 7 } \\
\text { minutes of } \\
\text { oxidation } \\
\text { time }\end{array}$ & $\begin{array}{l}\text { Every 3 } \\
\text { minutes of } \\
\text { oxidation } \\
\text { time }\end{array}$ & $\begin{array}{l}\text { Every 1.5 } \\
\text { minutes of } \\
\text { oxidation } \\
\text { time }\end{array}$ \\
\hline $\begin{array}{l}\text { Protocol } \\
\text { characterization } \\
\text { sampling times in } \\
\text { terms of test duration } \\
\text { (minutes) }\end{array}$ & $\begin{array}{l}0,133,267, \\
400,533, \\
\text { and 613 }\end{array}$ & $\begin{array}{l}0,93,187, \\
280, \text { and } \\
333\end{array}$ & $\begin{array}{l}0,40,80, \\
\text { and 133 }\end{array}$ & $\begin{array}{l}0,20,40, \\
\text { and 67 }\end{array}$ \\
\hline
\end{tabular}

compositions. The $\mathrm{pH}$ and turbidity of the feed solutions were monitored throughout the tests, and the temperature of the feed solution was maintained at $22{ }^{\circ} \mathrm{C}$. The feed flow rate for each test was 40 gallons per minute.

\section{TEST APPARATUS}

The pilot test unit is the Peroxidation Systems, Inc. perox-pure Model SSB-30. The unit is constructed of stainless steel and is equipped with six, high intensity, 5-kilowatt ultraviolet lamps. Each lamp is individually enclosed in a quartz sheath and each is wired to separate a switch so that any one can be independently operated, depending on the desired ultraviolet light energy input. Figure 2 shows the flow diagram with the process instrumentation for the ultraviolet light mediated oxidation pilot-scale testing. 


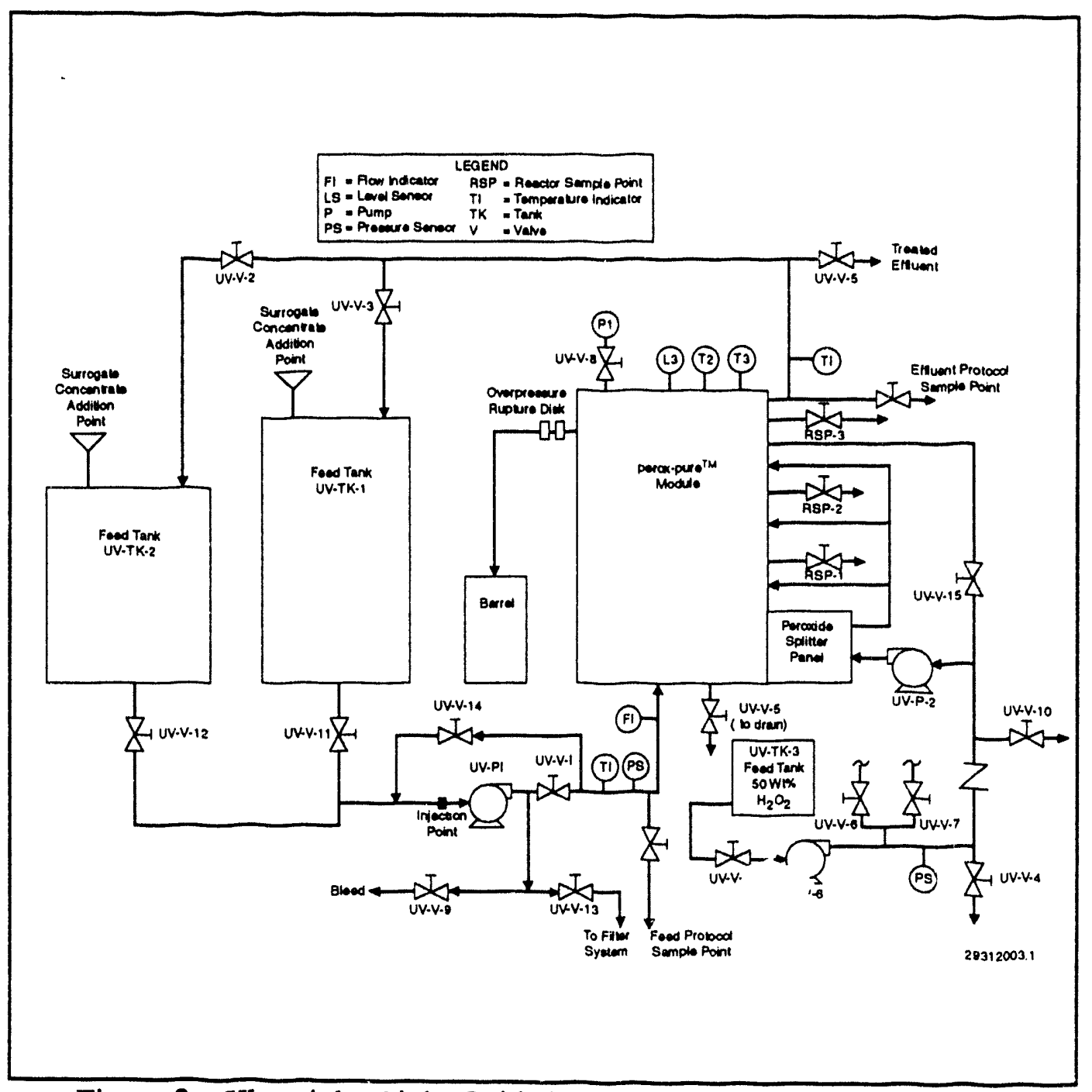

Figure 2. Ultraviolet Light Oxidation Test Apparatus Flow Diagram

The pilot-scale ultraviolet light mediated oxidation unit does not have a quartz sheath cleaning mechanism. The quartz sheath can be cleaned chemically or by removing the sheath from the reactor and wiping it with an absorbent cloth. Before and after each test run, the quartz sheaths were cleaned to maintain them as close as possible to the original condition for each test.

A hydrogen peroxide flow splitter can be used to inject hydrogen peroxide into the pilot-scale reactor at three locations. A pump meters the correct amount of hydrogen peroxide to the flow splitter, and the flow splitter divides preset amounts of hydrogen peroxide into the first, middle, and last sections of the reactor. For these tests the hydrogen peroxide was equally divided to each reactor section. 


\section{SAMPLE ANALYSIS}

With one exception, the analytical methods used for organic analysis followed EPA SW-846 methods [6]. The semivolatile organic compound analysis was performed using the Contract Laboratory Program (CLP) analysis method [7]. This method is similar to SW-846 Method 8270. The CLP analysis method was preferred for semivolatile organic compounds because quinones and resorcinol compounds were lost in the SW-846 Method 8270 extraction process.

Throughout the tests, hydrogen peroxide levels were determined with colormetric indicator strips which compared the color from a strip dipped into the sample with the color of a strip dipped into a standard of known concentration. Standards of 50, 70, 90, and 100 milligrams per liter $(\mathrm{mg} / \mathrm{L})$ were obtained for the Hanford Standards Laboratory. The range of the strips is 0 to $100 \mathrm{mg} / \mathrm{L}$. Samples, in which the hydrogen peroxide concentrations exceeded the concentrations of the standards, were diluted to bring the samples within the range of the standards as verified by the indicator strips.

\section{RESULTS}

Tables IV through VII summarize the organic data collected from these tesis, and Figure 3 shows the results for total organic carbon in which the concentration is plotted versus time. Plotted concentrations and sample times were normalized to the concentration at time zero and the length of the test respectively so that destruction of the organic compounds could be compared between tests. The oxidation times and hydrogen peroxide concentrations were chosen to compensate for the type and concentration of the inorganic constituents and the type and concentration of the organic compounds incorporated into the STSs. By normalizing the concentrations and oxidation times, the capability of the ultraviolet light mediated oxidation system to compensate for the different feed composition of the STSs can be seen. Figure 3 shows that by varying oxidation times and hydrogen peroxide concentrations, the ultraviolet light mediated oxidation system was able to decrease the total organic carbon concentration more than 80 percent before 40 percent of the testing time had expired for STS-1, STS-2, and STS-3. These three surrogates had the same organic compounds but in different concentrations or in different inorganic matrices. Although the fourth surrogate behaved differently, the end result was the same.

Figures 4 and 5 summarize the destruction achieved. Figure 4 compares the amount of each organic chemical destroyed in STS-1, STS-2, and STS-3. The organic and inorganic compounds were the same for the first three surrogates, but the concentrations of the chemical compounds varied between the surrogate solutions. Figure 5 shows the destruction of the organic compounds in STS-4. 
TABLE IV. ORGANIC ANALYTICAL DATA FOR STS-1.

\begin{tabular}{|c|c|c|c|c|c|c|c|}
\hline Analytes & $\begin{array}{c}\text { Target } \\
\text { concentration }\end{array}$ & $\begin{array}{l}\text { System } \\
\text { feed }\end{array}$ & $\begin{array}{c}\text { S. mple } \\
\text { time }= \\
133^{[\mathrm{b}]}\end{array}$ & $\begin{array}{c}\text { Sample } \\
\text { time }= \\
267^{[b]}\end{array}$ & $\begin{array}{c}\text { Sample } \\
\text { time }= \\
400^{[\mathrm{b}]}\end{array}$ & $\begin{array}{c}\text { Sample } \\
\text { time }= \\
533^{[b]}\end{array}$ & $\begin{array}{c}\text { Sample } \\
\text { time }= \\
613^{[b]}\end{array}$ \\
\hline & $\mathrm{ppb}$ & $\mathrm{ppb}$ & $\mathrm{ppb}$ & $\mathrm{ppb}$ & $\mathrm{ppb}$ & $\mathrm{ppb}$ & $\mathrm{ppb}$ \\
\hline Acetone & 25,000 & 14,000 & 3,200 & 150 & 26 & $10^{[a]}$ & $10^{[a]}$ \\
\hline Benzene & 2,500 & 1,700 & 2.5 & 3 & 1 & $5^{[a]}$ & 1 \\
\hline n-Butanol & 100,000 & 120,000 & $100^{[2]}$ & $100^{[a]}$ & $100^{[a]}$ & $100^{[2]}$ & $100^{[2]}$ \\
\hline $\begin{array}{l}\text { Carbon } \\
\text { tetrachloride }\end{array}$ & 2,500 & 480 & 37 & 13 & 4 & 2 & 2 \\
\hline Chloroform & 2,500 & 1,900 & 875 & 290 & 120 & 52 & 29 \\
\hline $\begin{array}{l}\text { Methyl ethyl } \\
\text { ketone }\end{array}$ & 5,000 & 5,300 & $10^{[a]}$ & $10^{[\mathrm{a}]}$ & $10^{[a]}$ & $10^{[2]}$ & $10^{[a]}$ \\
\hline $\begin{array}{l}\text { Methyl isobutyl } \\
\text { ketone }\end{array}$ & 5,000 & 5,800 & $10^{[a]}$ & $10^{[\mathrm{n}]}$ & $10^{[\mathrm{n}]}$ & $10^{[a]}$ & $10^{[2]}$ \\
\hline Toluene & 2,500 & 1,000 & 1 & $5^{[a]}$ & $5^{[0]}$ & $5^{[a]}$ & $5^{[n]}$ \\
\hline $\begin{array}{l}1,1,1- \\
\text { Trichloroethane }\end{array}$ & 2,500 & 1,300 & 725 & 220 & 86 & 32 & 16 \\
\hline Naphthalene & 2,500 & 1,900 & $10^{[2]}$ & $10^{[\mathrm{a}]}$ & $10^{[a]}$ & $10^{[a]}$ & $10^{[a]}$ \\
\hline Phenol & 2,500 & 2,700 & $10^{[x]}$ & $10^{[a]}$ & $10^{[a]}$ & $10^{[a]}$ & $10^{[2]}$ \\
\hline Pyridine & 2,500 & $100^{[a]}$ & $50^{[\mathrm{a}]}$ & $50^{[2]}$ & $50^{[a]}$ & $50^{[a]}$ & $50^{[a]}$ \\
\hline $\begin{array}{l}\text { Tributyl } \\
\text { phosphate }\end{array}$ & 15,000 & 15,000 & $20^{[a]}$ & $20^{[0]}$ & $20^{[a]}$ & $20^{[a]}$ & $20^{[2]}$ \\
\hline Tridecane & 1,000 & 780 & 430 & 150 & 85 & 40 & 21 \\
\hline TOC & $107,830^{[\mathrm{c}]}$ & 90,890 & 26,225 & 6,400 & 224 & 894 & 679 \\
\hline
\end{tabular}

[a] Analyte reported below detection limit, detection limit reported.

[b]Sample times reported in minutes of test duration, oxidation time is equal to test duration time multiplied by (15/200).

${ }^{[c]}$ Target TOC is the sum of the carbon in the organic compounds. 
TABLE V. ORGANIC ANALYTICAL DATA FOR STS-2.

\begin{tabular}{|c|c|c|c|c|c|c|}
\hline \multirow[t]{2}{*}{ Analytes } & $\begin{array}{c}\text { Target } \\
\text { concentration }\end{array}$ & $\begin{array}{c}\text { System } \\
\text { feed }\end{array}$ & $\begin{array}{c}\text { Sample } \\
\text { time }= \\
93^{\text {[b] }}\end{array}$ & $\begin{array}{c}\text { Sample } \\
\text { time }= \\
187^{[b]}\end{array}$ & $\begin{array}{c}\text { Sample } \\
\text { time }= \\
280^{[b]}\end{array}$ & $\begin{array}{c}\text { Sample } \\
\text { time }= \\
333^{[b]}\end{array}$ \\
\hline & $\overline{\mathrm{ppb}}$ & ppb & ppb & ppb & $\mathrm{ppb}$ & $\mathrm{ppb}$ \\
\hline Acetone & 2,500 & 3,900 & 650 & 120 & 50 & 34 \\
\hline Benzene & 250 & 210 & 2 & 1 & 1 & $5^{[a]}$ \\
\hline n-Butanol & 10,000 & 36,000 & $100^{[a]}$ & $100^{[\mathrm{s}]}$ & $100^{[\mathrm{s}]}$ & $100^{[\mathrm{a}]}$ \\
\hline Carbon tetrachloride & 250 & 120 & 59.5 & 22 & 12 & 9 \\
\hline Chloroform & 250 & 260 & 130 & 59 & 34 & 25 \\
\hline Methyl ethyl ketone & 500 & 820 & $10^{[0]}$ & $10^{[n]}$ & $10^{[2]}$ & $10^{[0]}$ \\
\hline $\begin{array}{l}\text { Methyl isobutyl } \\
\text { ketone }\end{array}$ & 500 & 470 & $10^{[a]}$ & $10^{[\mathrm{a}]}$ & $10^{[a]}$ & $10^{[n]}$ \\
\hline Naphthalene & 250 & 160 & $10^{[(x)}$ & $10^{[(s)}$ & $10^{[\mathrm{s}]}$ & $10^{[(s]}$ \\
\hline Toluene & 250 & 150 & $5^{[n]}$ & $5^{[\mathrm{l}]}$ & $5^{[2]}$ & $5^{[0]}$ \\
\hline 1,1,1-Trichloroethane & 250 & 170 & 115 & 44 & 25 & 16 \\
\hline Phenol & 250 & 210 & $10^{[a]}$ & $10^{[a]}$ & $10^{\text {[a] }}$ & $10^{[0]}$ \\
\hline Pyridine & 250 & $100^{[\mathrm{s}]}$ & $50^{[a]}$ & $50^{[\mathrm{n}]}$ & $50^{[a]}$ & $50^{[0]}$ \\
\hline Tributyl phosphate & 10,000 & 8,000 & $20^{[\mathrm{s}]}$ & $20^{(\mathrm{s})}$ & $20^{[a]}$ & $20^{[a]}$ \\
\hline Tridecane & 1,000 & 530 & 315 & 150 & 93 & 72 \\
\hline TOC & $16,144^{[\mathrm{cc}]}$ & 11,680 & 2,890 & 1,355 & 788 & 234 \\
\hline
\end{tabular}

${ }^{[a]}$ Analyte reported below detection limit, detection limit reported.

${ }^{[b]}$ Sample times reported in minutes of test duration, oxidation time is equal to test duration time multiplied by $(15 / 200)$.

${ }^{[s]}$ Target TOC is the sum of the carbon in the organic compounds. 
TABLE VI. ORGANIC ANALYTICAL DATA FOR STS-3.

\begin{tabular}{|c|c|c|c|c|c|}
\hline \multirow[t]{2}{*}{ Analytes } & $\begin{array}{c}\text { Target } \\
\text { concentration }\end{array}$ & $\begin{array}{l}\text { System } \\
\text { feed }\end{array}$ & $\begin{array}{c}\text { Sample } \\
\text { time }= \\
40^{[b]}\end{array}$ & $\begin{array}{c}\text { Sample } \\
\text { time }= \\
80^{[b]}\end{array}$ & $\begin{array}{c}\text { Sample } \\
\text { time }= \\
133^{[b]}\end{array}$ \\
\hline & ppb & $\mathrm{ppb}$ & $\mathrm{ppb}$ & $\mathrm{ppb}$ & $\mathrm{ppb}$ \\
\hline Acetone & 2,500 & 1,800 & 200 & $10^{(n)}$ & $10^{[a]}$ \\
\hline Benzene & 250 & 270 & 8 & 4 & 3 \\
\hline n-Butanol & 10,000 & 7,100 & $100^{[\mathrm{s}]}$ & $100^{[a]}$ & $100^{[a]}$ \\
\hline Carbon tetrachloride & 250 & 150 & 67.5 & 41 & 19 \\
\hline Chloroform & 250 & 290 & 104.5 & 31 & 6 \\
\hline Methyl ethyl ketone & 500 & $\overline{78}$ & $10^{[n]}$ & $10^{\text {(n) }}$ & $10^{[\mathrm{a}]}$ \\
\hline $\begin{array}{l}\text { Methyl isobutyl } \\
\text { ketone }\end{array}$ & 500 & 390 & $10^{[a]}$ & $10^{(n)}$ & $10^{[2]}$ \\
\hline Toluene & 250 & 180 & 4 & $5^{(n)}$ & $5^{[n]}$ \\
\hline 1,1,1-Trichloroethane & 250 & 240 & 100 & 28 & $5^{[2]}$ \\
\hline Naphthalene & 250 & 130 & $10^{[1]}$ & $10^{[\mathrm{s}]}$ & $10^{[n]}$ \\
\hline Phenol & 250 & 180 & $10^{[a]}$ & $10^{[n]}$ & $10^{[a]}$ \\
\hline Pyridine & 250 & $50^{[a]}$ & $50^{[\mathrm{a}]}$ & $50^{(x)}$ & $50^{[(1)}$ \\
\hline Tributyl phosphate & 10,000 & 4,900 & $20^{[a]}$ & $20^{[n]}$ & $20^{[a]}$ \\
\hline Tridecane & 1,000 & 130 & 195 & 77 & 150 \\
\hline TOC & $16,144^{[0]}$ & 10,500 & 1,440 & 280 & 180 \\
\hline
\end{tabular}

${ }^{[a]}$ Analyte reported below detection limit, detection limit reported.

${ }^{\text {bb }}$ Sample times reported in minutes of test duration, oxidation time is equal to test duration time multiplied by $(15 / 200)$.

${ }^{[c]}$ Target TOC is the sum of the carbon in the organic compounds. 
TABLE VII. ORGANIC ANALYTICAL DATA FOR STS-4.

\begin{tabular}{|c|c|c|c|c|c|}
\hline \multirow[t]{2}{*}{ Analytes } & $\begin{array}{c}\text { Target } \\
\text { concentration }\end{array}$ & $\begin{array}{l}\text { System } \\
\text { feed }\end{array}$ & $\begin{array}{c}\text { Sample } \\
\text { time }= \\
20^{[b]}\end{array}$ & $\begin{array}{c}\text { Sample } \\
\text { time }= \\
40^{[b]}\end{array}$ & $\begin{array}{c}\text { Sample } \\
\text { time }= \\
67^{[\mathrm{b}]}\end{array}$ \\
\hline & $\mathrm{ppb}$ & $\mathrm{ppb}$ & $\mathrm{ppb}$ & $\mathrm{ppb}$ & $\mathrm{ppb}$ \\
\hline Acetone & 0 & 18 & 250 & 11 & 140 \\
\hline Acetonitrile & 2,500 & 12 & 14.5 & 14 & 13 \\
\hline Acrolein & 2,500 & 2,400 & 190 & 21 & $20^{[2]}$ \\
\hline Benzene & 0 & 16 & 16.5 & 12 & $\overline{13}$ \\
\hline n-Butanol & 10,000 & 8,900 & 650 & $100^{[2]}$ & $100^{[a]}$ \\
\hline Chloroform & 0 & 8 & 7 & 7 & $\overline{5}$ \\
\hline Tetrachloroethylene & 2,500 & 1,200 & 465 & 340 & 240 \\
\hline Tetrahydrofuran & 5,000 & 5,300 & 210 & $5^{[0]}$ & $5^{[a]}$ \\
\hline 1,1,2-Trichloroethane & 2,500 & 2,400 & 2,100 & 1,900 & 1,000 \\
\hline Aniline & 5,000 & 2,700 & 355 & 14 & $20^{[2]}$ \\
\hline Elis(2-chloroethyl) ether & 2,500 & 1,700 & 270 & 12 & $10^{[2]}$ \\
\hline Flis (2-ethylhexyl) phthalate & 100 & 59 & 41 & 17 & 14 \\
\hline 1,4-dichlorobenzene & 5,000 & 1,900 & 35.5 & $5^{[a]}$ & $10^{[a]}$ \\
\hline gamma-BHC & 2,000 & 1,400 & 1,300 & 670 & 190 \\
\hline Hexachloroethane & 2,500 & 930 & 855 & 710 & 570 \\
\hline Nitrobenzene & 5,000 & 3,300 & 145 & 2 & $10^{[2]}$ \\
\hline $\mathrm{N}$-nitroso-di-n-propylamine & 2,500 & 1,450 & 5 & $10^{[a]}$ & $10^{[a]}$ \\
\hline Pentachlorophenol & 2,500 & 1,500 & 6 & $20^{[\mathrm{s}]}$ & $20^{[a]}$ \\
\hline T'ributyl phosphate & 10,000 & 4,800 & 63 & $20^{[(2)}$ & $20^{[a]}$ \\
\hline Tridecane & 1,000 & 360 & 360 & 140 & 140 \\
\hline TOC & $32,918^{[0]}$ & 21,000 & \begin{tabular}{|l|}
17,4450 \\
\end{tabular} & 13,170 & 792 \\
\hline
\end{tabular}

[a] Analyte reported below detection limit, detection limit reported.

${ }^{[b]}$ Sample times reported in minutes of test duration, oxidation time is equal to te:st duration time multiplied by $(15 / 200)$.

${ }^{[c]}$ Target TOC is the sum of the carbon in the organic compounds. 


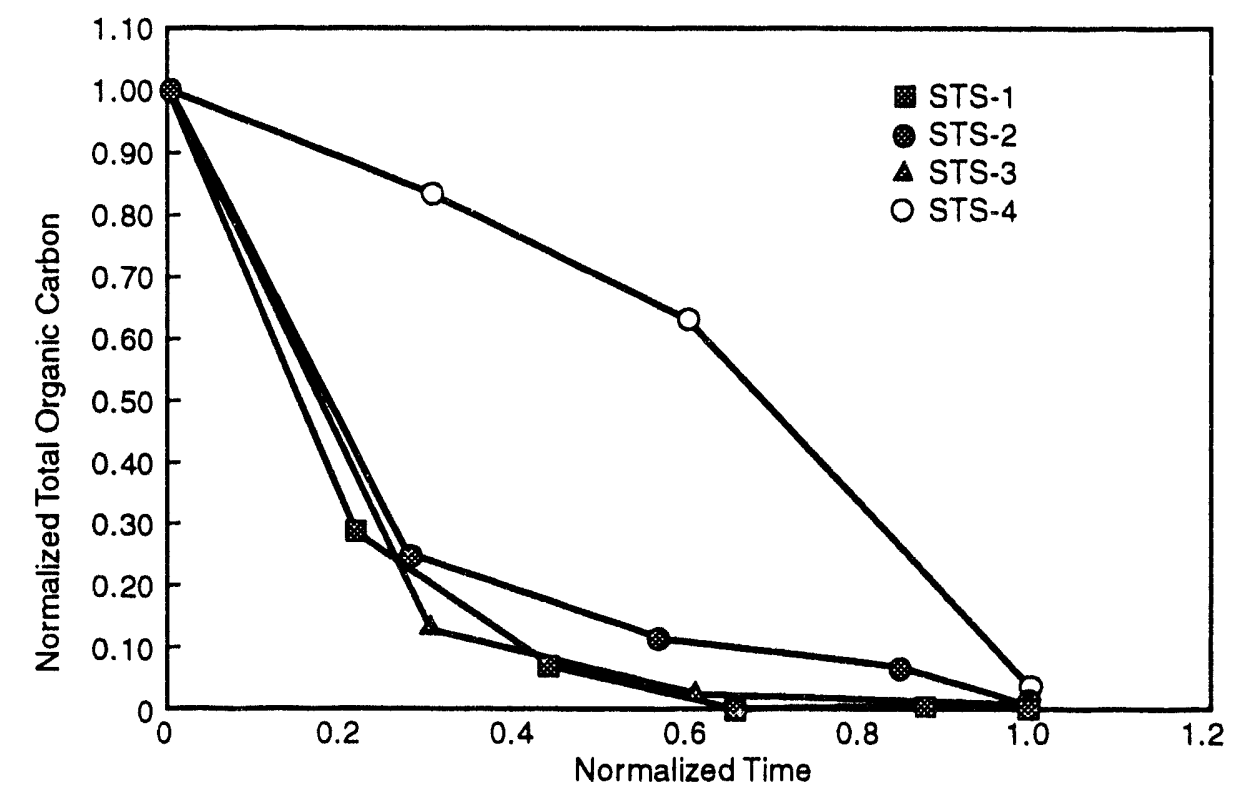

29312003.4

Figure 3. Normalized Total Organic Carbon Concentration Plotted versus Normalized Time. conducted:

The results of each test are discussed below in the order in which the tests were STS-1

Most of the organic compounds except the chlorocarbons and tridecane, were reduced to less than their detection limits. More than 99 percent of all compounds were destroyed.

The analytical results for tridecane seem to be most consistent in this test. Possibly, the substantial amount of 1-butanol added (100,000 micrograms per liter) helped dissolve the tridecane in the water. Therefore, consistent amounts of tridecane were available in the water for extraction and injection into the analytical instrument. 

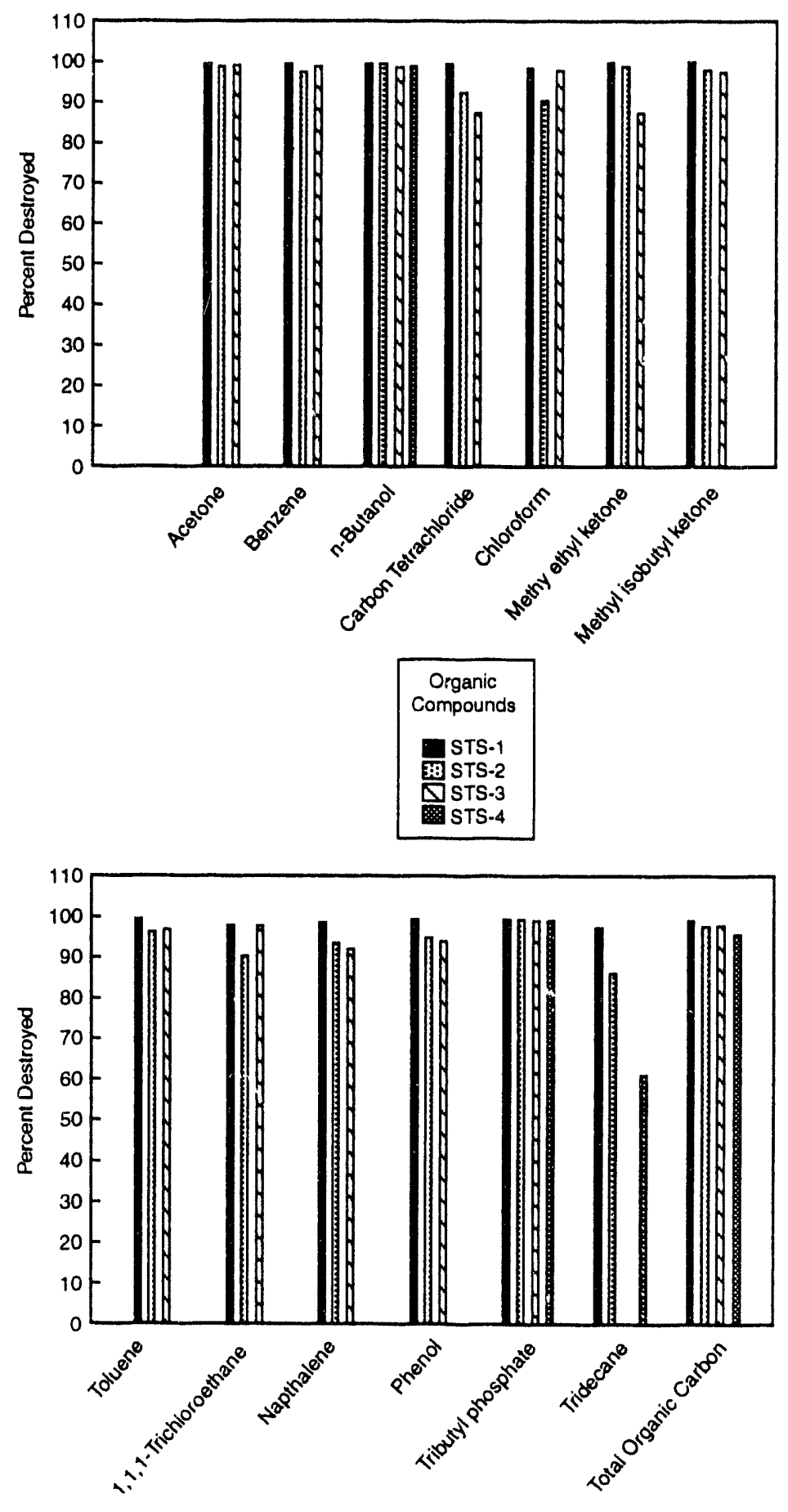

Figure 4. Summary of Destruction Efficiencies. 


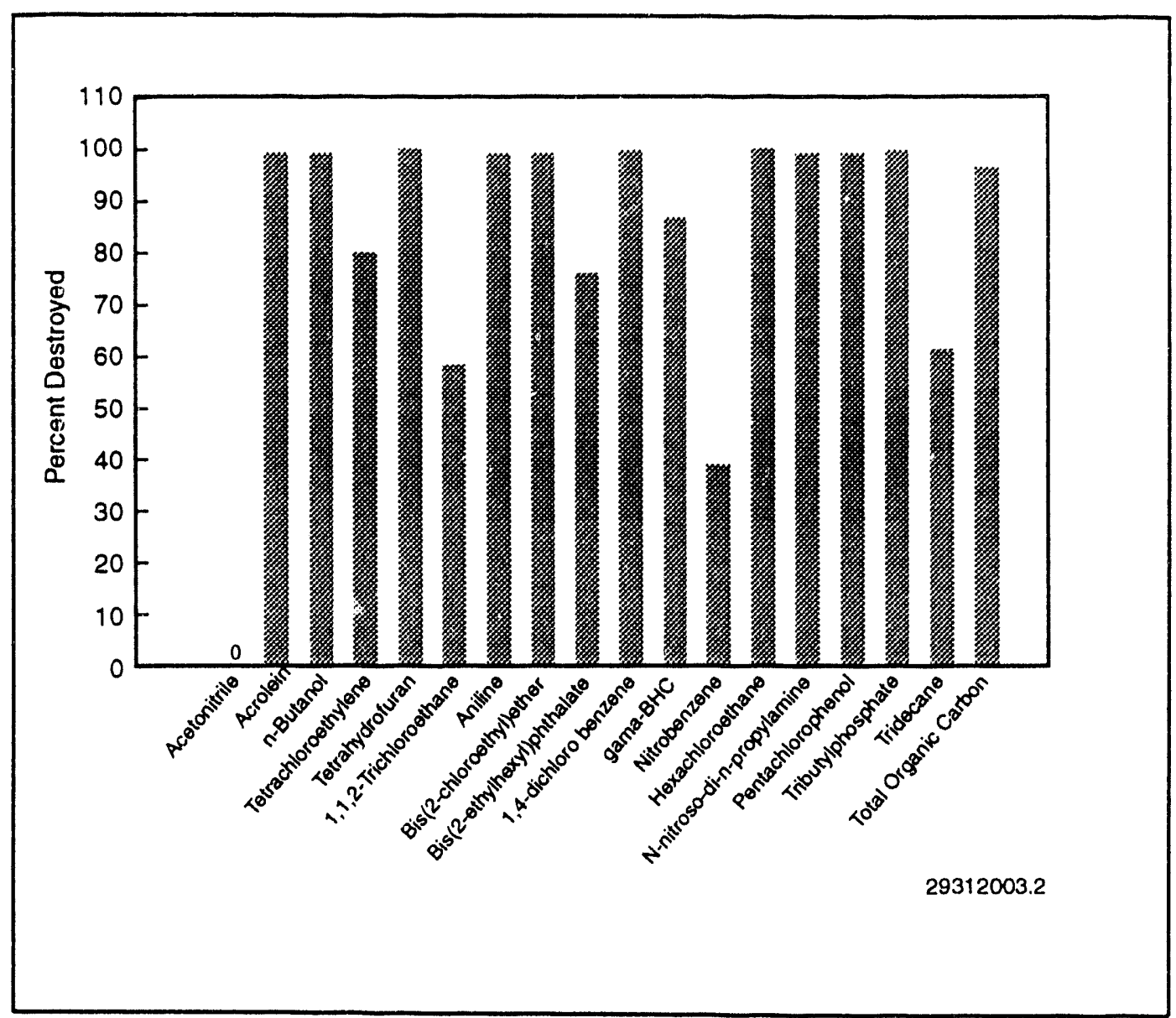

Figure 5. Destruction Frequencies for STS-4.

\section{STS-2}

Most of the organic compounds were reduced to less than detection limits. Exceptions included the following: acetone, carbon tetrachloride, chloroform, 1,1,1-trichloroethane, and tridecane. At 68 percent, 1,1,1-trichloroethane was the most resistant to destruction while more than 90 percent of all other organic compounds were destroyed. 


\section{STS-3}

All the organic compounds except the chlorocarbons and tridecane were reduced to less than their detection limits. The tridecane results were so erratic that conclusions cannot be drawn. More than 87 percent of each chlorocarbon was destroyed. The chlorocarbons and straight chain hydrocarbons appeared to be the most difficult to destroy.

STS-4

The chlorocarbons and tridecane were the most difficult to destroy. Thirty-nine percent of the hexachlorobenzene was removed. Of the compounds that are not straight chain hydrocarbons or chlorocarbons, only bis (2-ethyl hexyl) phthalate had less that 99 percent of the original concentration destroyed.

Acetone and chloroform, which may have been produced as degradation products, were subsequently destroyed. Chloroform may have been introduced as a contaminant in the deionized water used to prepare the solutions.

\section{CONCLUSIONS}

This testing showed that by adjusting operating conditions the perox-pure ultraviolet light mediater oxidation system was capable of processing feed streams that deviated significantly from the design basis. By varying the oxidation time and hydrogen peroxide concentration it was possible to obtain high levels of destruction for a wide variety of organic compounds in a matrix of low levels and high levels of inorganic compounds.

The chlorocarbon and straight chain hydrocarbon compounds were the most difficult to destroy, but significant levels of destruction were achieved.

\section{ACKNOWLEDGMENTS}

The authors would like to acknowledge the contributions of Tim P. Moberg, Craig V. King, Don E. Gana, Deirell D. Paine, and Phillip M. Olson.

\section{REFERENCES}

1. WAC 173-303, "Dangerous Waste Regulations," Washington State Department of Ecology, Olympia, Washington. 
2. 40 CFR 261, "Identification and Listing of Hazardous Waste," Title 40, Code of Federal Regulations, Part 261, U.S. Environmental Protection Agency, Washington, D.C.

3. WHC, 1992, C-018H Surrcgate Test Solution, WHC-SD-C018H-TS-001, Rev. 0, Westinghouse Hanford Company, Richland, Washington.

4. WHC, 1993, Envelope Test Plan, WHC-SD-C018H-TP-009, Rev. 0, Westinghouse Hanford Company, Richland, Washington.

5. WHC, 1990, Inventory of Chemicals Used at Hanford Site Production Plants and Support Operations (1994-1980), WHC-EP-0172, Revision 1, Westinghouse Hanford Company, Richland, Washington.

6. EPA, 1987, Test Methods for Evaluating Solid Waste, Physical/Chemical Methods, SW-846, Update II issued 1990, U.S. Environmental Protection Agency, Washington, D.C.

7. EPA, 1991, Statement of Work for Organic Analysis Contract Laboratory Program EPA OLM 01.8, U.S. Environmental Protection Agency, Washington, D.C. 

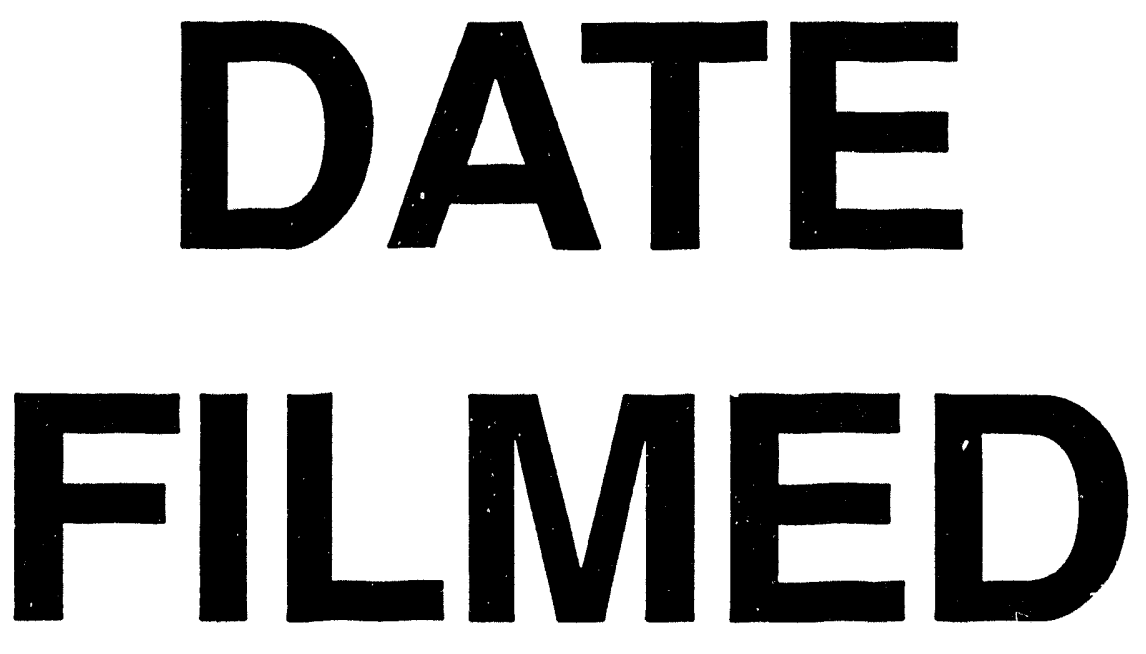

$9 / 12 / 94$
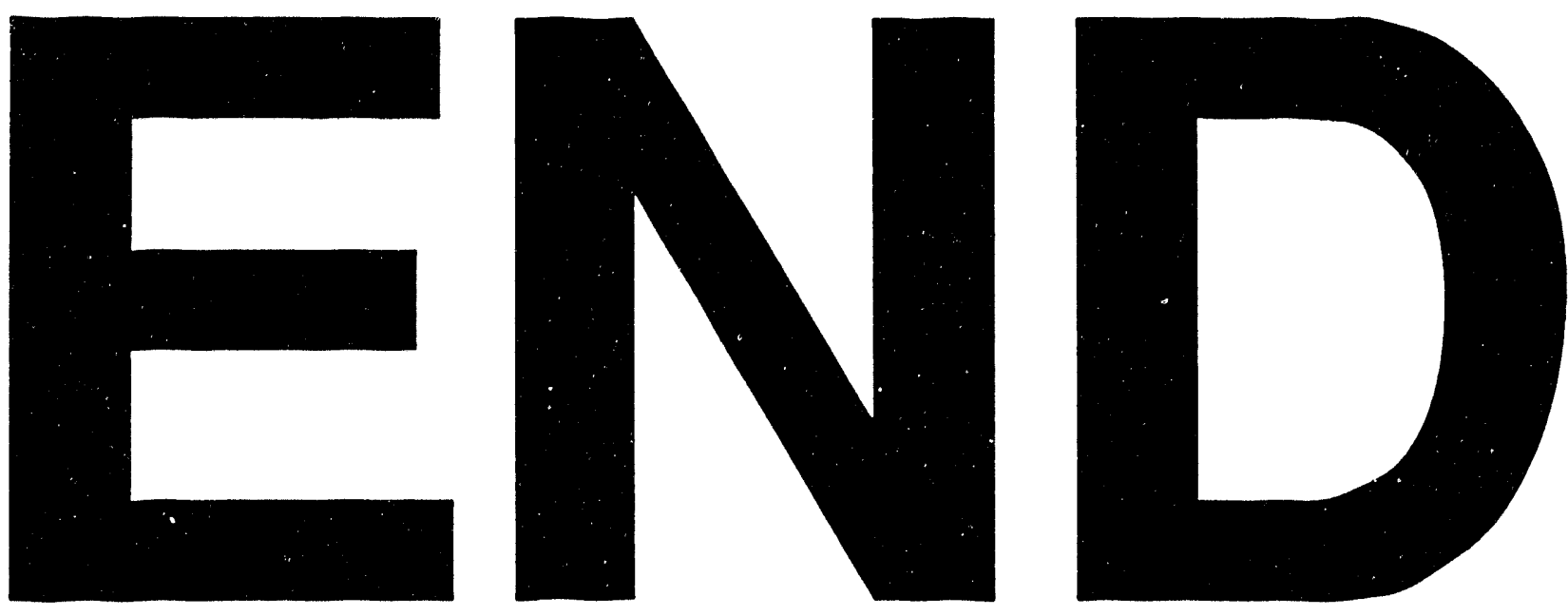
1 